\title{
Odontoma Removal and Oral Rehabilitation via Insertions of Albumin and Gentamycin Coated Bone Allograft and Dental Implants - A Case Report
}

\author{
Fanni Minya, Balint Trimmel, Laszlo Simonffy, Csaba Dobo-Nagy and Szabolcs Gyulai-Gaal* \\ Department of Oral Diagnostics, Faculty of Dentistry, Semmelweis University, Hungary
}

*Corresponding author: Szabolcs Gyulai-Gaal, Department of Oral Diagnostics, Faculty of Dentistry, Semmelweis

University, Budapest, Hungary

\begin{tabular}{|c|c|}
\hline ARTICLE INFO & ABSTRACT \\
\hline Received: 㓞 February 02, 2021 & $\begin{array}{l}\text { Odontomas are the most frequently diagnosed odontogenic tumors. Odontomas } \\
\text { usually are asymptomatic or may be associated with tooth impaction or aplasia because }\end{array}$ \\
\hline Published: 幽 February 08, 2021 & $\begin{array}{l}\text { of an obstructive impact on tooth eruption. Odontoma requires surgical removal and } \\
\text { following surgery, the adjacent impacted tooth may spontaneously erupt; otherwise, }\end{array}$ \\
\hline $\begin{array}{l}\text { itation: Fanni Minya, Balint Trimmel, } \\
\text { aszlo Simonffy, Csaba Dobo-Nagy, } \\
\text { zabolcs Gyulai-Gaal. Odontoma Removal } \\
\text { nd Oral Rehabilitation via Insertions of } \\
\text { llbumin and Gentamycin Coated Bone } \\
\text { lllograft and Dental Implants - A Case } \\
\text { Report. Biomed J Sci \& Tech Res 33(5)- } \\
\text { 021. BJSTR. MS.ID.005450. }\end{array}$ & $\begin{array}{l}\text { a surgical-orthodontic treatment is necessary. When an odontoma is associated with } \\
\text { a tooth aplasia, an orthodontic space-closure may be the appropriate treatment } \\
\text { option. When the space deriving from a missing tooth is too wide, it can be treated by } \\
\text { prosthetic method or dental implant. When dental implantation is the planned option the } \\
\text { strengthening and augmentation of bony bed may be necessary. Preventive approach via } \\
\text { alveolar preservation can be useful at the time of odontoma removal to facilitate further } \\
\text { surgical treatment and implantation. The presented case reports on the removal of an } \\
\text { odontoma coupled with alveolar preservation, bone grafting and dental implantation. }\end{array}$ \\
\hline
\end{tabular}

Keywords: Albumin; Allograft; Alveolar Preservation; Dental Implant; Gentamycin; Odontoma

\section{Introduction}

Odontoma is the most common odontogenic tumor showing about $75 \%$ occurrence rate followed by lower incidences of ameloblastoma and odontogenic myxoma [1]. Odontomas are considered to be hamartomas joining to the developmental anomalies of teeth [2]. Local traumatism, infection and inherited genetic factors may be considered as potential etiological factors. Genetic disorders in Gardner and Herman syndrome may be associated with the development of multiplex odontomas [3,4]. Clinically two types of odontomas may be differentiated according to their location. Central odontoma is located intraosseusly, while the extremely rare peripheral odontoma can be found in the soft tissues. Both lesions are more prevalent in the anterior region of maxilla and mandible, with nearly a same incidence rate in both jaws [5-7]. Gender predilection of the incidence of odontoma could not be revealed $[1,5]$. Histologically compound and complex odontomas may be distinguished; their incidence rate is 2:1 [5]. Compound odontoma is composed of several tooth-like small denticles. Complex odontoma exhibits less matured structure with an amorphous, partly mineralized mixture of enamel, dentin, cement and pulp tissue [8]. Odontomas are usually asymptomatic and they can be accidentally diagnosed in case of dental radiological examination [9]. It may usually be diagnosed in young patients at age 20-30. Several dentitional anomalies can refer to the presence of an odontoma; persisting deciduous tooth, delayed tooth eruption and missing or impacted permanent tooth. In certain cases, a growing odontoma may break through the gingival mucosa and the appearance of a hard tissue tumor in the fenestration mimics a tooth eruption $[6,10]$. In the presented case, an unusual inflammatory process associated with an anomalous tooth eruption suggested the presence of jaw tumor.

The treatment of odontoma requires interdisciplinary approach. Odontoma requires surgical removal via local excision. The clinical diagnosis may be verified by histological examination. Unlike other tumors, odontoma shows no inclination to recurrence. When the odontoma involves the periapical region of adjacent teeth causing devitalization or root resorption, root canal treatment, sometimes 
combined with apectomy may be necessary [11]. Early diagnosis is important approximately at the age of 10 years when orthodontic treatment is needed. The odontoma forms a physical obstacle which hinders the eruption of teeth. When an odontoma causes tooth impaction, the impacted tooth can spontaneously erupt after the removal of physical obstruction, otherwise surgical-orthodontic treatment is necessary [12-14]. When a permanent tooth is missing because of developmental failure, orthodontically space closure can be performed especially in childhood $[15,16]$. After the age of 18 , when the jaw development has finished, the missing tooth can be replaced by a prosthetic restorative treatment or a dental implant [17]. The choice depends on the general physical status of the patient and on the quality and quantity of the surrounding jawbone. Before the insertion of a dental implant the available bone amount has to be estimated. When the odontoma is small, an immediate implantation may be possible after its removal [18]. Usually, the removal of the odontoma results in a large bone defect, thus bone augmentation might be necessary before the insertion of implant $[19,20]$. Preservation of alveolar bone is a preventive approach during the odontoma removal facilitating further oral rehabilitation.

\section{Results - Case Report}

A 31-year-old male patient exhibited a painful palatal swelling when he arrived for dental examination (Figure 1a). Stomato- oncological screening was carried out, no premalignant or malignant lesions were found [21]. His upper right canine was missing, and a deciduous lateral incisor replaced the permanent one. The orthopantomogram showed an approximately $2 \mathrm{~cm}$ sized rounded formation of small radio opaque structures including two smaller rudimentary teeth, being probably the impacted canine and lateral incisor teeth (Figure 1b). The clinical diagnosis was compound odontoma. The lesion erupted to the oral cavity and the dental follicle was infected. The palatal abscess was drained for emptying a purulent exudate through the palatal incision. Since both the permanent canine and lateral incisor were impacted, the treatment plan was to enucleate the whole tumor together with the unerupted teeth and then to replace the missing teeth with dental implants and crowns. During the first surgical intervention the deciduous lateral incisor was removed. An incision was performed on the alveolar ridge completed with a buccal vertical release incision creating an L shaped mucoperiosteal flap. The odontoma was partially removed in several pieces using forceps and elevator (Figure 2a\&2b). The cranial part of the odontoma was preserved as its removal would require sacrificing a great amount of maxillary bone. The partial preservation of odontoma helped to spare an appropriate bone mass, which was necessary for the further prosthetic rehabilitation (Figure 2c). The flap was primarily fixed via sutures. The histological examination confirmed the clinical diagnosis of complex odontoma.
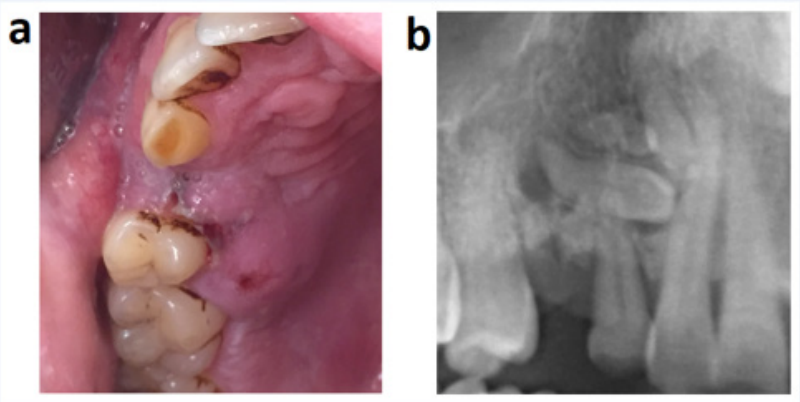

Figure 1: Preoperative images;

a. Palatal swelling, persistent deciduous lateral incisor, missing canine.

b. Radiographic image of odontoma.
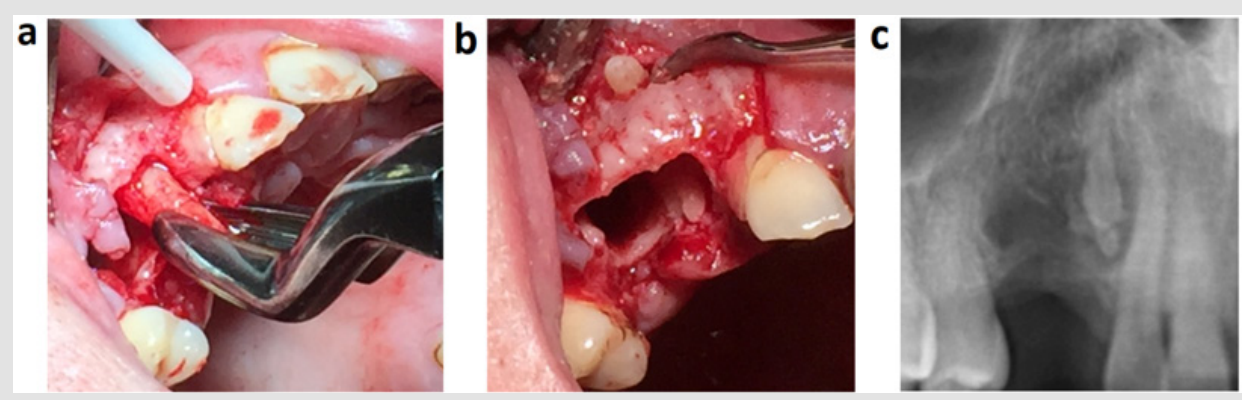

Figure 2: First surgical exposure of odontoma
a. Partial odontoma delivery.
b. Remained bone defect.
c. Radiographic image after the first surgery. 
After 3 months the cranial part of the odontoma was placed near to the occlusal plate and it could be easily removed via a second operation. During the exposure of the odontoma remnant a buccal bone ridge was preserved to minimalize the bone loss (Figure 3a). Thorough excochleation was performed and the complete removal of tumor was confirmed by radiological examination. The bone defect was filled with bone allograft particles coated with albumin and gentamycin (Figure 3b). Antibiotics were prescribed after both surgeries; amoxicillin/clavulanic acid 875/125 mg 2 times a day for one week. Adverse reactions were not experienced during the healing period. After 6 months the radiographic image showed complete graft integration and bone remodeling (Figure 3c). The next step of treatment was the implant placement. An L-shaped flap was prepared similarly like at the time of odontoma removal. The clinical findings confirmed a complete bone healing; the examined area was appropriate for implant placement without further bone augmentation. Two Astra 4,0*11 mm dental implants were placed which had $25 \mathrm{Ncm}$ primer stability (Figure 4a). After a 3-month healing, the implants were exposed and two porcelain-fused-tometal crowns were fixed with cement in one piece. After a threeyear follow up the crown-mucosa junction was intact and less than $1 \mathrm{~mm}$ bone loss could be observed (Figure $4 \mathrm{~b} \& 4 \mathrm{c}$ ). a

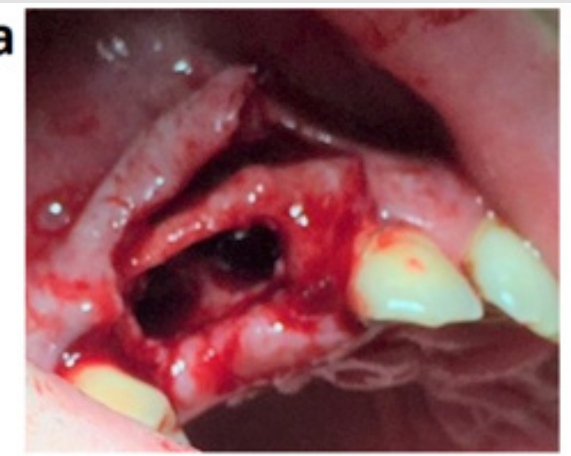

b

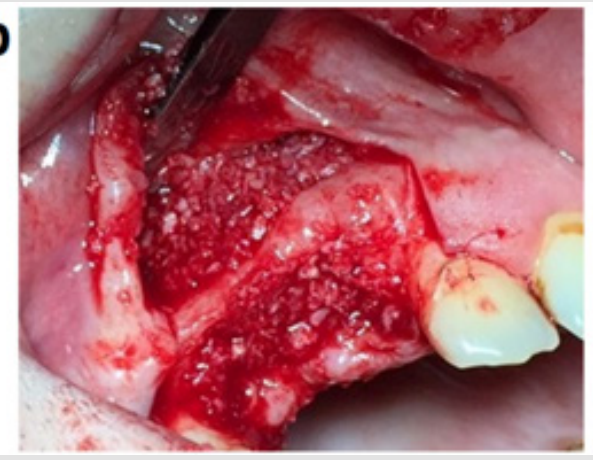

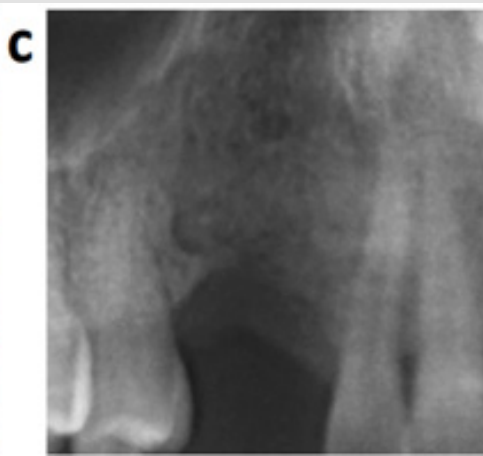

Figure 3: Second surgical exposure of odontoma;

a. Bone defect with the remaining buccal bone ridge after the complete removal of odontoma.

b. Bone augmentation with albumin and gentamycin coated allograft.

c. Radiographic image of the augmented bone 6 months postoperatively.

\section{a}

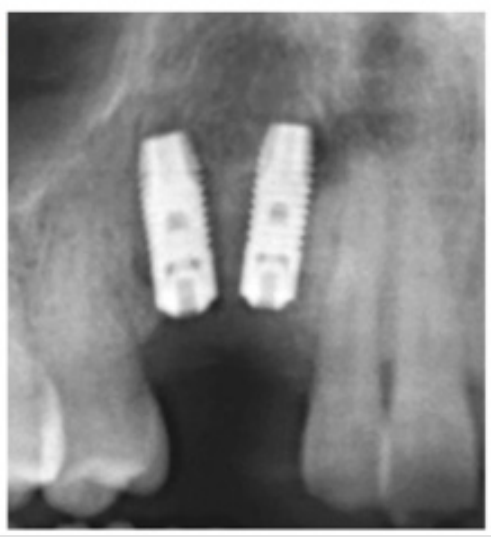

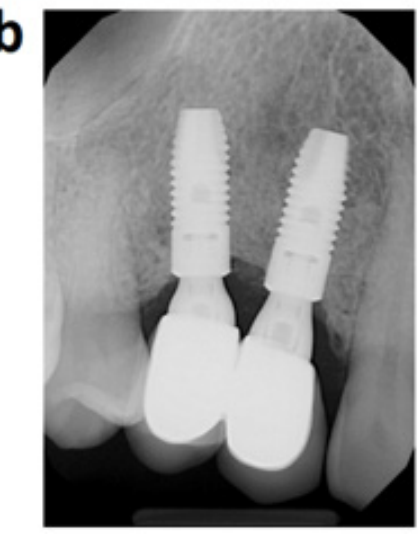

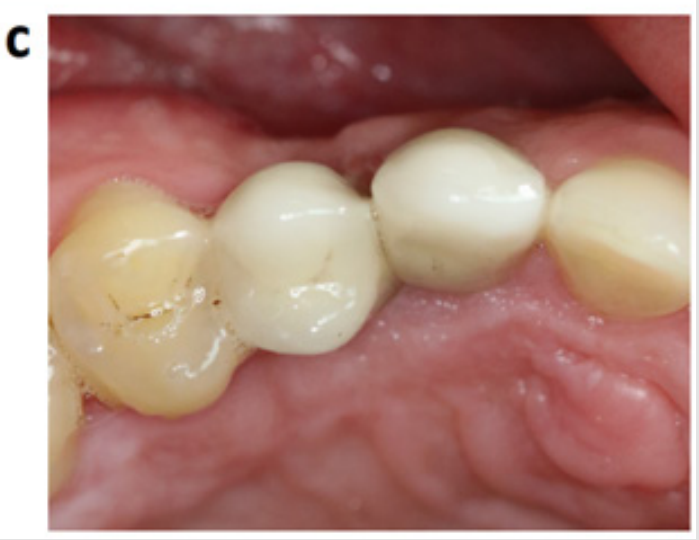

Figure 4: Tooth restoration

a. Radiographic image after the implant placement.

b. Radiographic image at 3-year control.

c. Oral status at 3-year control.

\section{Discussion}

The early diagnosis is crucial in cases with odontoma. The early treatment is essential as odontomas inhibit normal tooth eruption. The removal of tumors and orthodontic treatment improves the dental status of patients. The removal of odontoma has several risk factors like nerve damage and postoperative paresthesia, the injury of nearby teeth, wound dehiscence, and infection [22]. The removal of odontoma results in a bigger bone defect than it is usual after a surgical tooth extraction. Odontoma removal is a risk of bone fracture especially when the odontoma is positioned in the angular 
region of mandible [23]. When odontoma is associated with tooth aplasia the narrow place can hinder tooth replacement when it was planned with dental implants. The surgical treatment of odontoma should be thoroughly planned and properly performed as both prosthetic and orthodontic aspects should be considered [24]. The presented case shows the importance of bone preservation in order to facilitate further oral rehabilitation and tooth replacement. Bone augmentation is a well-known technique in oral surgery and implantology. Several methods and materials are available to enhance bone mass for implant placement [25]. Bone augmentation and implant insertion is performed later, months or years after tooth removal; however, alveolar preservation may prevent the need of bone replacement [26]. Bone grafting after cystectomy is also a preventive approach so as to facilitate the possibility of oral rehabilitation [27]. This presented case demonstrates that bone grafting can also be an option associated with surgical removal of odontoma.

A wide range of bone grafting materials may be available. The allograft coated by human albumin is highly valuable when it is used for alveolar preservation and bone augmentation, resulting in improved graft integration and remodeling [28-30]. The allograft has the same structure as the host area, while the osteoinductive capacity of albumin enhances bone regeneration. In vitro and in vivo experiments justified that albumin shows adhesion and proliferation increasing effects on bone marrowderived mesenchymal stem cells, thus albumin coated allograft resulted in faster and stronger bone formation than uncoated allografts [31,32]. In addition, the albumin activates a higher number of immunomodulatory cytokines and growth factors, and the gentamycin coating of graft ensure antibiotic release for several weeks $[33,34]$. Consequently, albumin and gentamycin coated allograft can be an excellent option when bone grafting is necessary in a complicated case of bone loss.

\section{References}

1. Buchner A, Merrell PW, Carpenter WM (2006) Relative frequency of central odontogenic tumors: a study of 1,088 cases from Northern California and comparison to studies from other parts of the world. J Oral Maxillofac Surg 64(9): 1343-1352.

2. Gyulai Gaál S, Takács D, Barabás J, Tarján I, Martonffy K, et al. (2007) Fogelőtörési zavarokkal járó vegyes odontogén daganatok. Fogorvosi szemle 100(2): 65-69.

3. Erden Sahin MB, Calis A, Koca H (2020) An unusual case of 177 pieces of mandibular compound odontoma: 10-year follow-up. J Stomatol Oral Maxillofac Surg 121(5): 585-588.

4. Bordini J, Contar CM, Sarot JR, Fernandes A, Machado MA (2008) Multiple compound odontomas in the jaw: case report and analysis of the literature. J Oral Maxillofac Surg 66(12): 2617-2620.

5. Hidalgo Sánchez O, Leco I, Martínez González J (2008) Metaanalysis of the epidemiology and clinical manifestations of odontomas. Med Oral Patol Oral Cir Bucal 64(9): 1343-1352.

6. de Oliveira MA, Reis B, Pallos D, Kim YJ, Braz Silva PH, Martins F (2019) The Importance of Histopathological Examination to the Final Diagnosis of Peripheral Odontogenic Tumors: A Case Report of a Peripheral Odontoma. Case Rep Dent: 9712816.
7. Avelar RL, Primo BT, Pinheiro Nogueira CB, Studart Soares EC, de Oliveira RB, et al. (2011) Worldwide incidence of odontogenic tumors. J Craniofac Surg 22(6): 2118-2123.

8. Gyulai Gaál S, Takács D, Szabó G, Suba Z (2007) Mixed odontogenic tumors in children and adolescents. J Craniofac Surg 18(6): 1338-1342.

9. Bródy A, Zalatnai A, Csomo K, Belik A, Dobo C (2019) Difficulties in the diagnosis of periapical translucencies and in the classification of cemento-osseous dysplasia. BMC Oral Health 19.

10. Shekar S, Rao RS, Gunasheela B, Supriya N (2009) Erupted compound odontome. J Oral Maxillofac Pathol 13(1): 47-50.

11. Flores Orozco EI, Abu Hasna A, Teotonio de Santos Junior M, Flores Orozco EI, Falchete Do Prado R, et al. (2019) Case Report: Interdisciplinary management of a complex odontoma with a periapical involvement of superior anterior teeth. F1000Research 8: 1531.

12. Cildir SK, Sencift K, Olgac V, Sandalli N (2005) Delayed eruption of a mandibular primary cuspid associated with compound odontoma. J Contemp Dent Pract 6(4): 152-159.

13. Das UM, Viswanath D, Azher U (2009) A compound composite odontoma associated with unerupted permanent incisor: a case report. Int J Clin Pediatr Dent 2(2): 50-55.

14. Tarján I, Gyulai SG, Soós A, Rózsa N (2005) Tuberculate and odontoma type supernumerary teeth. J Craniofac Surg 16(6): 1098-1102.

15. Thilander B (2008) Orthodontic space closure versus implant placement in subjects with missing teeth. J Oral Rehabil 35 Suppl 1: 64-71.

16. Robertsson S, Mohlin B (2000) The congenitally missing upper lateral incisor. A retrospective study of orthodontic space closure versus restorative treatment. Eur J Orthod 22(6): 697-710.

17. Gyulai Gaál S, Minya F, Trimmel B, Simonffy L (2019) Az implantológia helye a fogcsírahiányos esetek ellátásában. Fogorvosi Szemle 112(3): 77-81.

18. de Souza Batista FR, de Souza Batista VE, Vechiato Filho AJ, Tieghi Neto V, Figueira JA, et al. (2017) Immediate Dental Implant Placement After Removal of Complex Odontoma. J Craniofac Surg 28(8): e737-e738.

19. Utumi ER, Cremonini CC, Pedron IG, Zambon CE, Cavalcanti MG, et al. (2011) Maxillary reconstruction with particulate bone graft and titanium mesh: a treatment option for large complex odontoma of the maxilla. J Dent Child (Chic) 78(2): 124-128.

20. Lehman H, Lustmann J, Regev E (2013) Removal of an extensive mandibular odontoma using an intraoral approach. Quintessence Int 44(6): 425-428

21. Károly M, Szarka K, Mensch H, Dobai A, Magyar Z, et al. (2018) PCR Technique Assisting the Early Diagnosis of Human Papillomavirus A retrospective clinical study. Revista de Chimie 69: 2781-2787.

22. Arunkumar KV, Vijaykumar, Garg N (2012) Surgical management of an erupted complex odontoma occupying maxillary sinus. Ann Maxillofac Surg 2(1): 86-89.

23. Christopher PJ, Periasamy S, Devadoss P, Kumar SP (2017) Surgical Access to a Complex Composite Odontoma via Sagittal Split Osteotomy of the Mandible. Cureus 9(12): e1915.

24. Uma E (2017) Compound Odontoma in Anterior Mandible-A Case Report. Malays J Med Sci 24(3): 92-95.

25. Irinakis T, Tabesh M (2007) Preserving the socket dimensions with bone grafting in single sites: an esthetic surgical approach when planning delayed implant placement. J Oral Implantol 33(3): 156-163.

26. Avila Ortiz G, Gubler M, Romero Bustillos M, Nicholas CL, Zimmerman MB, et al. (2020) Efficacy of Alveolar Ridge Preservation: A Randomized Controlled Trial. J Dent Res 99(4): 402-409.

27. Pappalardo S, Guarnieri R (2013) Efficacy of Platelet-Rich-Plasma (PRP) and Highly Purified Bovine Xenograft (Laddec(®)) Combination in 
Bone Regeneration after Cyst Enucleation: Radiological and Histological Evaluation. J Oral Maxillofac Res 4(3): e3.

28. Kivovics M, Szabó BT, Németh O, Iványi D, Trimmel B, et al. (2020) Comparison between Micro-Computed Tomography and Cone-Beam Computed Tomography in the Assessment of Bone Quality and a LongTerm Volumetric Study of the Augmented Sinus Grafted with an Albumin Impregnated Allograft. J Clin Med 9(2): 303.

29. Simonffy L, Minya F, Trimmel B, Lacza Z, Dobo Nagy C (2020) AlbuminImpregnated Allograft Filling of Surgical Extraction Sockets Achieves Better Bone Remodeling Than Filling with Either Blood Clot or Bovine Xenograft. Int J Oral Maxillofac Implants 35(2): 297-304.

30. Márton K, Tamás SB, Orsolya N, Béla C, Ferenc D, Péter N, et al. (2018) Microarchitecture of the Augmented Bone Following Sinus Elevation with an Albumin Impregnated Demineralized Freeze-Dried Bone Allograft (BoneAlbumin) versus Anorganic Bovine Bone Mineral: A Randomized Prospective Clinical, Histomorphometric, and MicroComputed Tomography Study. Materials (Basel) 11(2): 202.

ISSN: 2574-1241

DOI: 10.26717/BJSTR.2021.33.005450

Szabolcs Gyulai-Gaal. Biomed J Sci \& Tech Res

(C) (P) This work is licensed under Creative

Submission Link: https://biomedres.us/submit-manuscript.php
31. Weszl M, Skaliczki G, Cselenyák A, Kiss L, Major T, et al. (2012) Freezedried human serum albumin improves the adherence and proliferation of mesenchymal stem cells on mineralized human bone allografts. J Orthop Res 30(3): 489-496.

32. Skaliczki G, Schandl K, Weszl M, Major T, Kovács M, et al. (2013) Serum albumin enhances bone healing in a nonunion femoral defect model in rats: a computer tomography micromorphometry study. Int Orthop 37(4): 741-745.

33. Hornyák I, Madácsi E, Kalugyer P, Vácz G, Horváthy DB, et al. (2014) Increased release time of antibiotics from bone allografts through a novel biodegradable coating. Biomed Res Int 2014: 459867.

34. Mijiritsky E, Gardin C, Ferroni L, Lacza Z, Zavan B (2020) Albuminimpregnated bone granules modulate the interactions between mesenchymal stem cells and monocytes under in vitro inflammatory conditions. Mater Sci Eng C Mater Biol Appl 110: 110678.

$\begin{array}{ll}\text { BIOMEDICAL } & \text { Assets of Publishing with us } \\ \text { RESEARCHES } & \text { - Global archiving of articles } \\ \text { - Immediate, unrestricted online access }\end{array}$

